SNEŽANA GOLUBOVIĆ

$902.2: 572.7(497.11)$

Institute of Archaeology,

904:726.8"652"(497.11)

Belgrade, Serbia

COBISS.SR-ID 228052748

arheosneska@gmail.com

ŽIVKO MIKIĆ

Original research article

Belgrade University, Faculty of Philosophy,

Received: February $14^{\text {th }} 2016$

Department of Archaeology,

Accepted: June $20^{\text {th }} 2016$

Belgrade, Serbia

\title{
RESULTS OF ARCHAEOLOGICAL-ANTHROPOLOGICAL STUDIES OF MASS BURIALS IN VIMINACIUM - GRAVE G-769 / THE PEĆINE NECROPOLIS
}

\begin{abstract}
This paper is the third of its kind, about the archaeological-anthropological analyses of mass burials excavated in Viminacium during the 20th century. It includes burials in the grave G-769, defined as a mass grave and containing a secondary burial of 25 skulls. During the anthropological analysis of these 25 skulls, other human skeletal remains were also defined. All individuals were male and were buried in their primary graves. At some point during the refurbishment of the necropolis, their skulls were taken from their original graves and buried together in a mass grave. Due to the lack of chronologically sensitive archaeological material (grave-goods), their dating was made by comparing with neighbouring graves. It was concluded that they were not younger than the middle of the 3rd century A.D.
\end{abstract}

\section{KEYWORDS: VIMINACIUM, NECROPOLIS, GRAVE, MASS BURIAL, SKULLS.}

During spring campaign of 1981, at the site of Pećine (Map. 1), in the northern part of trench 185 , a group of human and animal bones was examined and conditionally marked as grave G-769 (Fig. 1) ${ }^{1}$. The bones were discovered at a depth of $0.50 \mathrm{~m}$ down to a depth of $0.90 \mathrm{~m}$. They covered an area of $2 \mathrm{~m} 2$ that was inclined from the east to the west. There were 25 human skulls all together, partially fragmented and deformed, due soil settling. The skulls were marked with the letters A, B, C, D, E, F, G, H, I, J, K, L, LJ, M, N,

1 The article results from the project: Viminacium, Roman city and military camp - research of material and non- material culture of inhabitants by using the modern technologies of remote detection, geophysics, GIS, digitalization and 3D visualization (no 47018), funded by The Ministry of Education, Science and Technological Development of the Republic of Serbia.

* This paper is the third of its kind, about archaeological-anthropological analyses of mass burials excavated in Viminacium during the 20th century.
$\mathrm{O}, \mathrm{P}, \mathrm{R}, \mathrm{S}, \mathrm{T}, \mathrm{U}, \mathrm{V}, \mathrm{W}, \mathrm{X}$ and $\mathrm{Y}$. Three mandibles were discovered and a larger number of skull fragments. Apart from the skulls, there were about thirty fragments of long bones. Among the animal bones, there were 17 horse long bones, 12 cattle bones and a dog's skull. In the eastern part of the area, apart from the bones, there were also brick and stone fragments and pottery shards. ${ }^{2}$

\section{ANTHROPOLOGICAL FINDS AND PROCESSING METHOD}

Defined as a mass grave, G-769 contained a secondary burial of 25 skulls. During anthropological research of these 25 skulls, some human osteological material was also separated. These

2 Archaeological field diary, pp. $987-988$, from May $26^{\text {th }}$ 1981. 


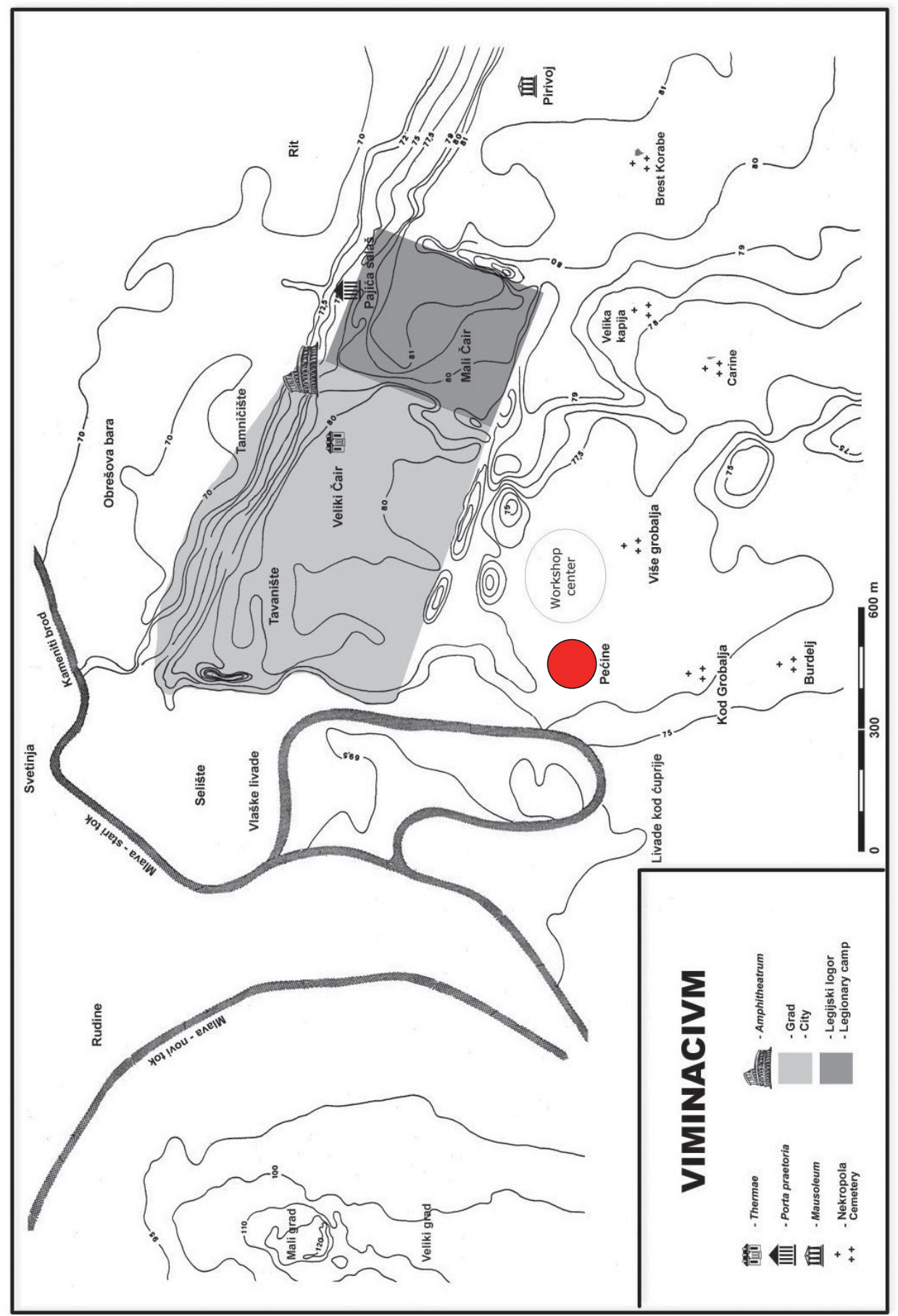

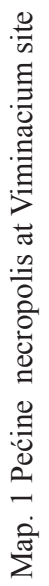

were fragments of skulls and mandibles from the agglomeration marked from A to Y. There is the possible presence of at least two other individuals, with at least four fragmented mandibles. However, during archaeological excavations, these fragmented human remains were not connected to the anthropological content of grave G-769, but were identified during anthropologic research. Nevertheless, in the field diary, fragmented parts of skulls and long bones are mentioned.

Generally, along with 25 reliably distinguished human skulls, there are remains of at least two other individuals. However, a question arises as to whether these remains can be connected with the previ- 


\begin{tabular}{|c|c|c|c|}
\hline $\begin{array}{l}\text { SKULL } \\
\text { MARK }\end{array}$ & NUMBER & GENDER & INDIVIDUAL AGE \\
\hline $\mathrm{A}$ & 1 & male & between 40 and 50 years \\
\hline B & 2 & male & between 30 and 40 years \\
\hline $\mathrm{C}$ & 3 & male & between 40 and 50 years \\
\hline $\mathrm{D}$ & 4 & male & between 30 and 40 years \\
\hline $\mathrm{E}$ & 5 & male & between 30 and 40 years \\
\hline $\mathrm{F}$ & 6 & male & over 50 years \\
\hline G & 7 & male & between 30 and 40 years \\
\hline $\mathrm{H}$ & 8 & male & between 40 and 50 years \\
\hline I & 9 & male & between 20 and 30 years \\
\hline $\mathrm{J}$ & 10 & male & between 40 and 50 years \\
\hline $\mathrm{K}$ & 11 & male & between 40 and 50 years \\
\hline $\mathrm{L}$ & 12 & male & between 30 and 40 years \\
\hline LJ & 13 & male & between 30 and 40 years \\
\hline M & 14 & male & adult \\
\hline $\mathrm{N}$ & 15 & male & adult \\
\hline $\mathrm{O}$ & 16 & male & adult \\
\hline $\mathrm{P}$ & 17 & male & adult \\
\hline $\mathrm{R}$ & 18 & male & adult \\
\hline $\mathrm{S}$ & 19 & male & adult \\
\hline $\mathrm{T}$ & 20 & male & adult \\
\hline $\mathrm{U}$ & 21 & male & between 40 and 50 years \\
\hline V & 22 & male & up to 25 years \\
\hline $\mathrm{W}$ & 23 & male & between 40 and 60 years \\
\hline $\mathrm{X}$ & 24 & male & adult \\
\hline $\mathrm{Y}$ & 25 & male & between 50 and 60 years \\
\hline
\end{tabular}

TABLE I: Viminacium/Pećine - G-769 - gender and age

Addendum tab. 1:

I - in the secondary position, the remains of at least two further male individuals were discovered;

II - fragments of at least four further mandibles have been identified, all of them male;

III - according to tooth abrasion in mandible fragments, the individual's age was between 20/25 and 45 years. 


\begin{tabular}{|c|c|c|c|c|c|c|c|c|c|c|c|c|}
\hline SKULL MARK & $\mathrm{A}$ & $\mathrm{B}$ & $\mathrm{C}$ & $\mathrm{D}$ & $\mathrm{E}$ & $\mathrm{F}$ & $\mathrm{G}$ & $\mathrm{H}$ & $\mathrm{I}$ & $\mathrm{J}$ & $\mathrm{K}$ & $\mathrm{L}$ \\
\hline GL-OP & 186 & 182 & 188 & 194 & 185 & 182 & 180 & 183 & 180 & 197 & 190 & 183 \\
\hline EU-EU & 140 & 146 & 142 & 139 & 143 & 144 & 142 & 146 & $(140)$ & 142 & 144 & 143 \\
\hline FT-FT & 102 & 98 & 104 & 99 & 101 & 97 & 99 & 100 & 97 & 98 & 94 & 100 \\
\hline BA-B & 120 & 122 & 119 & 122 & 124 & 126 & - & 130 & - & 124 & 126 & 130 \\
\hline PO-B & 112 & 116 & 112 & 114 & 112 & 101 & - & 115 & - & 108 & 112 & 109 \\
\hline ZY-ZY & 132 & 133 & 134 & 134 & - & - & - & 136 & 132 & - & - & - \\
\hline N-PR & 68 & 66 & 68 & 67 & - & - & - & 65 & 68 & - & - & - \\
\hline MF-EK & 36 & 37 & 37 & 37 & - & - & - & 38 & 36 & - & - & - \\
\hline $\begin{array}{c}\text { height of the } \\
\text { eye-socket }\end{array}$ & 34 & 35 & 33 & 32 & - & - & - & 36 & 34 & - & - & - \\
\hline $\begin{array}{c}\text { width of the } \\
\text { nose-socket }\end{array}$ & 24 & 26 & 22 & - & - & - & - & 25 & 24 & - & - & - \\
\hline $\begin{array}{c}\text { N-NS } \\
\text { GO-GO }\end{array}$ & - & - & 106 & - & - & - & - & $(108)$ & $(102)$ & - & - & - \\
\hline \begin{tabular}{c} 
GO-G5 \\
\hline
\end{tabular}
\end{tabular}

TABLE A II: Viminacium/Pećine - G-769 - primary skull measurements ( ) - denotes anthropological measurement obtained through reconstruction

ously mentioned 25 skulls or not. Basically, due to the poor and incomplete state of preservation, researchers were not able to establish reliable data.

Where the method of anthropological research is concerned, the same methodological principle was applied as when other mass graves from Viminacium were examined (Golubović, Mikić 2011: 173-184; Golubović, Mikić 2014: 163-184). Such citing avoids unnecessary repetition of the already established methodological elements and criteria, already quoted in this periodical.

\section{RESULTS OF THE ANTHROPOLOGICAL RESEARCH}

At the beginning of the anthropological research, it was easily noticed that the skulls from the upper layer, marked from A to L, were much better preserved and it was possible to make a standardised anthropological projection and to illustrate them (Fig. 2 - 5). This includes their osteometric processing, including primary skull measurements. The skulls marked from LJ to Y were not so well preserved and it was not possible to bring them into anatomic contexts through reconstruction. Only their paleo-demographic elements were obtained. As shown in the tables, the results are as follows: Table I shows the paleo-demographic elements for all 25 skulls. Table II shows the primary measurements for the 12 best preserved skulls.

During the early 1980s, in Serbia, there were no possibilities to analyse skeletons in any way other than using the classical anthropologic and morphologic-morphometric methods. According to this, also considering the poor state of preservation of finds from this grave with secondary skull burials, we were able to rely only on the classification of anthropological-statistics. For example, the basic skull index was calculated (length-width), in order to roughly examine the inner structure of the deceased from this Viminacium grave. Results of the length-width index of the cerebral skull part and its anthropologic classification are shown in table III:

According to the anthropological data obtained, it was possible to tell that the mass grave number 769 from Pećine contained 25 or even 27 male skulls, deposited as a secondary burial (Table I). The individual age of the deceased was between 20 and about 60 years of age. According to the prima- 


\begin{tabular}{|c|c|c|}
\hline INDEX VALUE & SKULL MARK & ANTHROPOLOGIC CATEGORY \\
\hline 71.64 & $\mathrm{D}$ & $\begin{array}{l}\text { DOLICHOCRANIC PART } \\
(70.00-74.90)\end{array}$ \\
\hline 72.08 & $\mathrm{~J}$ & \\
\hline 75.27 & A & \multirow{9}{*}{$\begin{array}{c}\text { MESO-DOLICHOCRANIC PART } \\
(75.00-79.90)\end{array}$} \\
\hline 75.53 & $\mathrm{C}$ & \\
\hline 75.79 & $\mathrm{~K}$ & \\
\hline 77.30 & $\mathrm{E}$ & \\
\hline$(77.78)$ & $\mathrm{I}$ & \\
\hline 77.89 & $\bar{G}$ & \\
\hline 78.14 & $\mathrm{~L}$ & \\
\hline 79.12 & $\mathrm{~F}$ & \\
\hline 79.78 & $\mathrm{H}$ & \\
\hline 80.22 & $\mathrm{~B}$ & $\begin{array}{c}\text { BRACHYCRANIC PART } \\
(80.00-84.90)\end{array}$ \\
\hline
\end{tabular}

TABLE III: Viminacium/Pećine - G-769 - overview of gradual growth of length-width index value, including its anthropologic classification:

( ) - denotes anthropological measurement obtained through reconstruction

ry skull measurements of the twelve best preserved skulls (Tables I - IV), the available osteometric diameters were obtained (Table II). The categorisation of the basic (length-width) index of the cerebral skull part indicates that they belonged to all of the morphologic categories (Table III). According to the only possible criteria of morphologic categorisation, the skulls showed less heterogeneity.

In 1993, Ž. Mikić published an overview of the Roman mass burials from Viminacium (Mikić 1993: 197-207), aiming to show their specificities and problems, since approximately one third of the inhabitants (out of 3,240 anthropologically examined skeletons) were buried in mass graves (548 graves: 1,411 skeletons). The grave G-769, from Pećine, was not included in this overview since, by 1990, it had not been anthropologically examined, due to the ongoing archaeological excavation. However, in this primarily statistical analysis, he did not separate primary from secondary burials, or partial ones from full ones. This is acceptable, since it would involve huge analysis, and a synthesis of all the specificities of ancient Viminacium would also be necessary. However, as experts continued to work on this topic, it was obvious that mass burials were not practiced only in graves in the shape of wells (Golubović, 2009), but there were also other forms of such graves, starting with two and with even up to 153 skulls (Mikić 1988a, 19-34; Mikić 1988b, 121-145). This paper represents a continuation of the research, since detailed archaeological and an- 


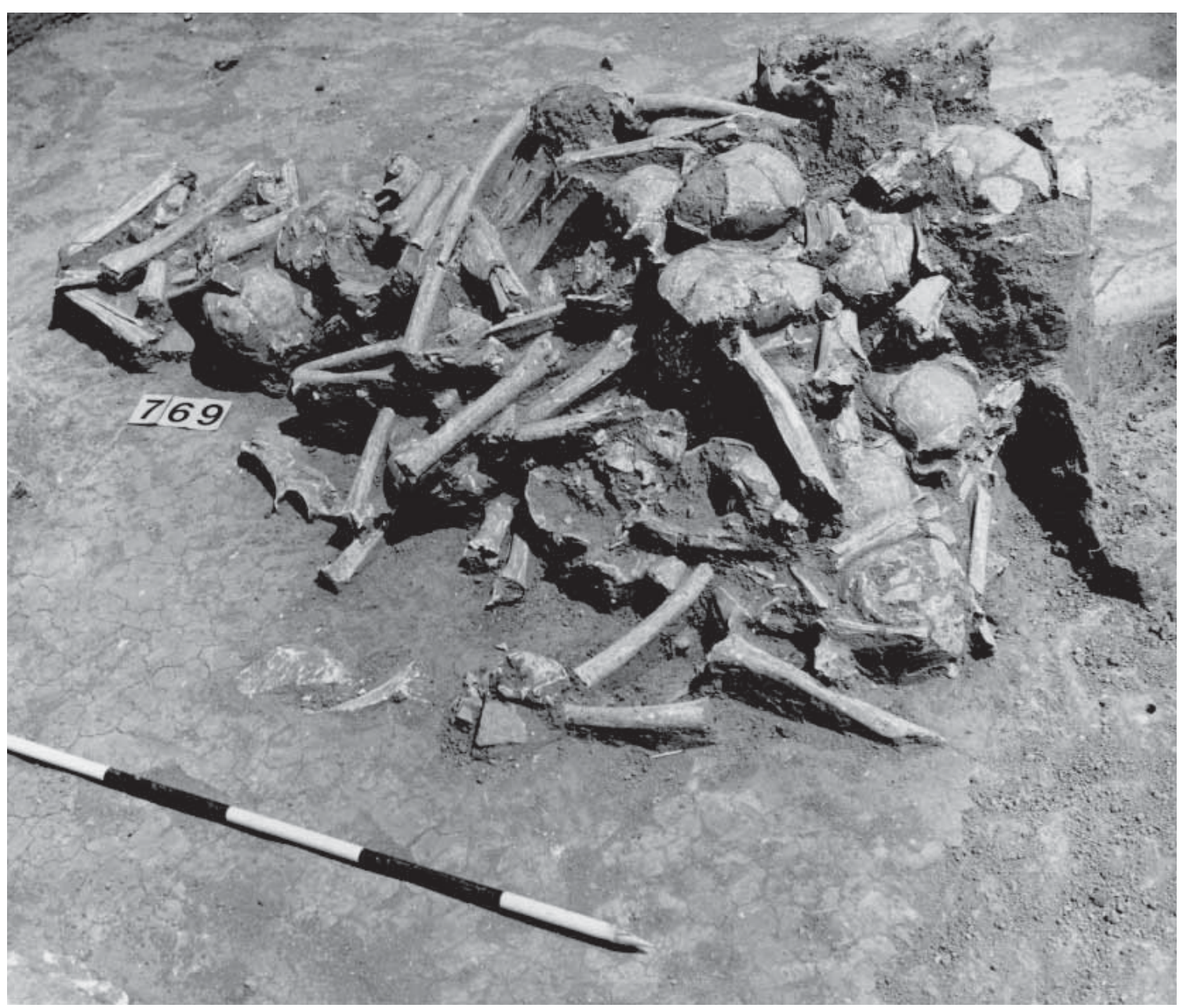

Fig. 1 Mass grave G-769.

thropological documentation about mass graves in Viminacium is available.

The case of the human bone material from grave G 769 at Pećine could lead to the same conclusion as grave G 4924 (Mikić 1988b, 143). In fact, individuals, in this case all of them male, possessed their primary graves, but then, at a certain point during the rearrangement of the necropolis, their skulls and some other parts of the post-cranial skeletons were taken out and buried together in a mass grave. Due to the lack of chronologically sensitive material (grave-goods), dating was obtained according to the neighbouring graves and it was concluded that they were not younger than the middle of the 3 rd century A.D. The fact is that the inhabitants from that period still respected the deceased, and the marking and respect of their new, secondary graves, could be accepted as a part of an already existing and developed post-funerary practice.

\section{BIBLIOGRAPHY}

\section{Golubović, S. and Mikić, Ž. 2011}

Results of the Archaeological-Anthropological Study of the Mass Burial at Viminacium - Grave G 2158 - The Pećine Necropolis, Arheologija $i$ prirodne nauke 7: 173-184.

\section{Golubović, S. and Mikić, Ž. 2014}

Results of the Archaeological-Anthropological Studies of Mass Burials in Viminacium - Grave in the Shape of a Well in the Handicraft Centre / the Pećine Necropolis, Arheologija i prirodne nauke 10: 163-184. 
Mikić, Ž. 1993

Viminacijum - pregled grupnih grobova rimskog perioda, Saopštenja XXV, Republički zavod za zaštitu spomenika kulture, Beograd: 197-207.

\section{Golubović, S. 2008}

Grobovi u obliku bunara sa nekropola Viminacijuma, Arheološki institut.

Mikić, Ž. 1988a

Rezultati epigenetske obrade masovnog groba 4924 sa antičkog Viminacijuma, Glasnik Antropološkog društva Jugoslavije 25, Beograd, Antropološko društvo Jugoslavije: 19-34.

Mikić, Ž. 1988b

Antropološki aspekti tumačenja nekih oblika sahrane na antičkom Viminacijumu, Godišnjak XXVI/24, Centar za balkanološka ispitivanja ANU BiH, Sarajevo: 121-145.

\section{REZIME}

REZULTATI ARHEOLOŠKOANTROPOLOŠKIH STUDIJA O GRUPNOM SAHRANJIVANJU U VIMINACIJUMU - GROB G-769/ NEKROPOLA PEĆINE

\section{KLJUČNE REČI: VIMINACIJUM, NEKROPOLA, GROB, GRUPNO SAHRANJIVANJE, LOBANJE.}

Rad predstavlja treći u nizu arheološko-antropoloških analiza grupnih grobova istraženih na Viminacijumu tokom XX veka i obradjuje sekundarnu sahranu u grupnom grobu.

Definisan kao grupni grob, G-769, sadržavao je sekundarnu sahranu 25 lobanja. Iz dobijenih antropoloških rezultata moglo se videti da je ovaj grob sadržavao 25, ili čak 27 muških lobanja zatečenih posle njihove sekundarne sahrane (tabela I). Individualna starost sahranjenih se kretala od oko 20 do oko 60 godina života. Sudeći prema primarnim lobanjskim merama 12 najbolje očuva- nih lobanja (table I - IV), dobijeni su i raspoloživi osteometrijski dijametri (tabela II). Kategorisanje osnovnog (dužinsko-širinskog) indeksa cerebralnog dela lobanja pokazuje da su one pripadale svim morfološkim kategorijama (tabela III). Sudeći prema ovom, jedino mogućem kriterijumu morfološke kategorizacije, lobanje su ispoljile manju heterogenost.

Na slučaj obrađenog humanog materijala iz groba G-769 sa Pećina, mogao bi se primeniti zaključak koji se odnosio i na G-4924 sa iste nekropole (Mikić 1988b, 143). Naime, individue, u ovom slučaju sve muškog pola, su imale svoje primarne grobove, a zatim su u nekom trenutku preuređenja nekropole, njihove lobanje i još neki delovi postkranijalnog skeleta uzeti iz primarnih i svi sahranjeni u masovni grob. Usled nedostatka hronološki osetljivog arheološkog materijala iz groba, datovanje je izvršeno prema odnosu sa susednim grobovima tako da je zaključeno da nisu mlađi od sredine III veka nove ere. Naravno i tumačenje da tadašnje stanovništvo i dalje poštuje pokojne srodnike, odnosno obeležava i poštuje njihove nove, sekundarne grobove može se prihvatiti kao deo već prihvaćene postfunerarne prakse. 
A
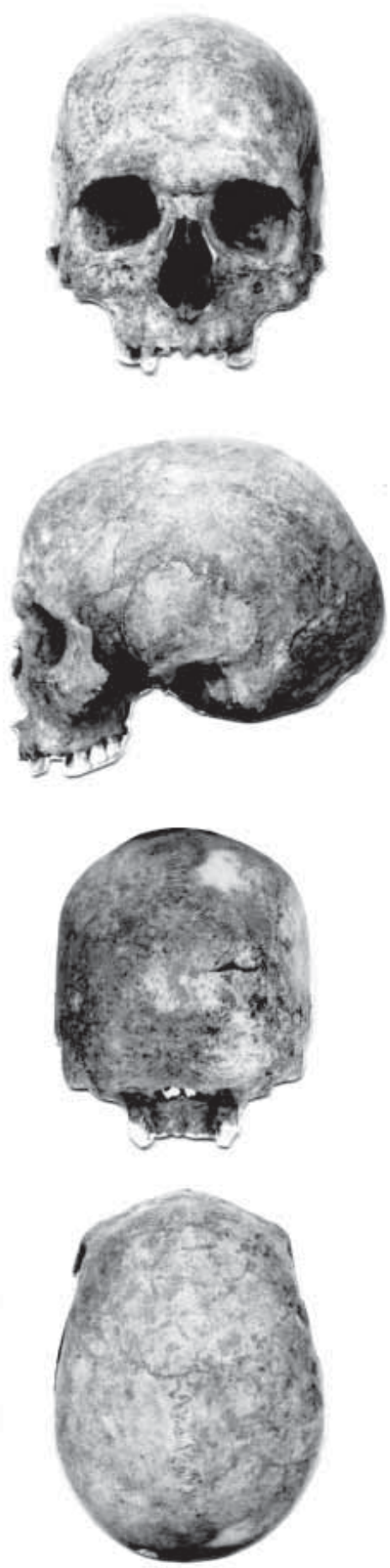

B
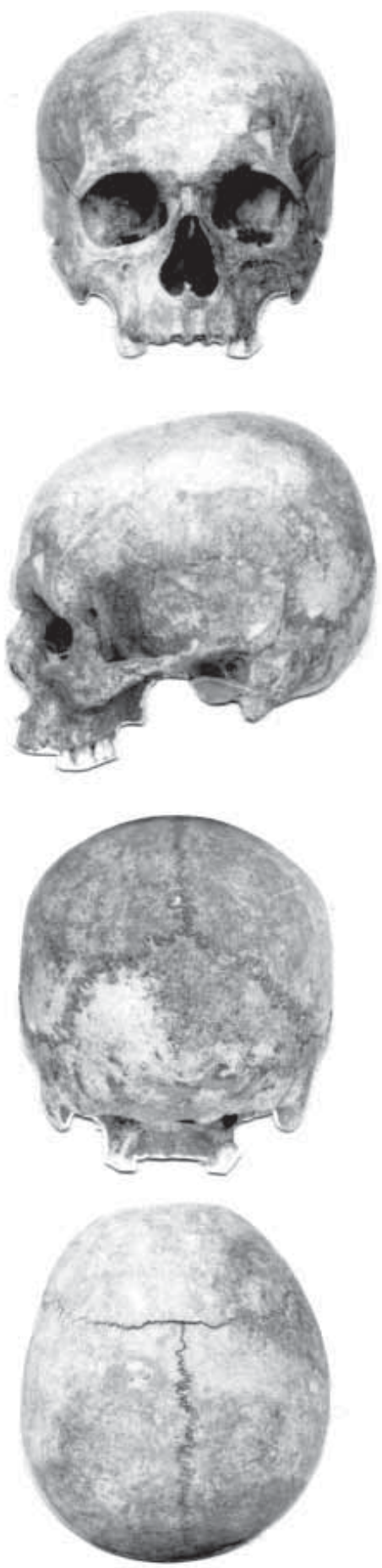

$\mathrm{C}$
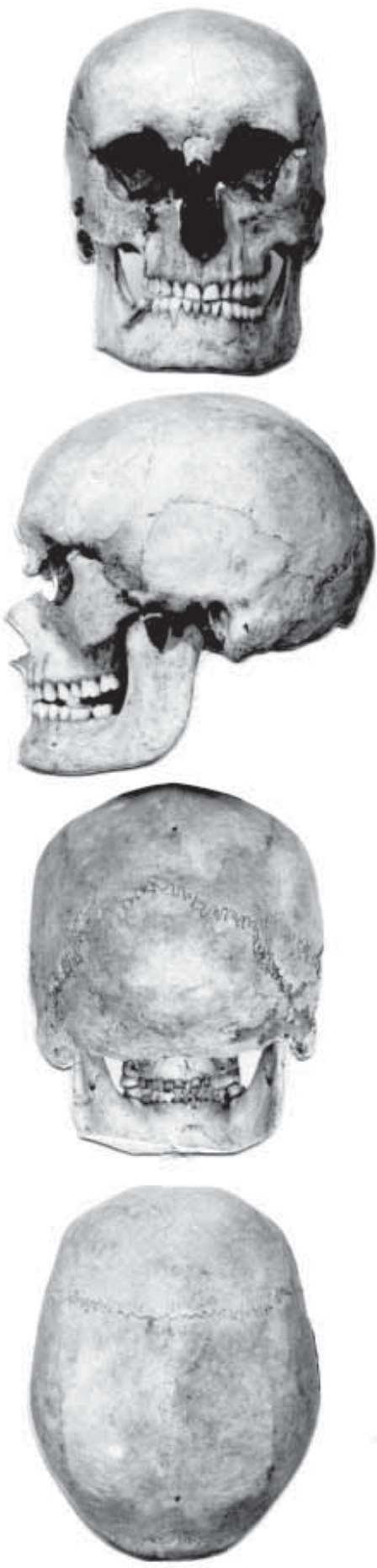

Fig. 2 Standardised anthropologic projection of skulls marked as A, B and C from grave G-769. 
D
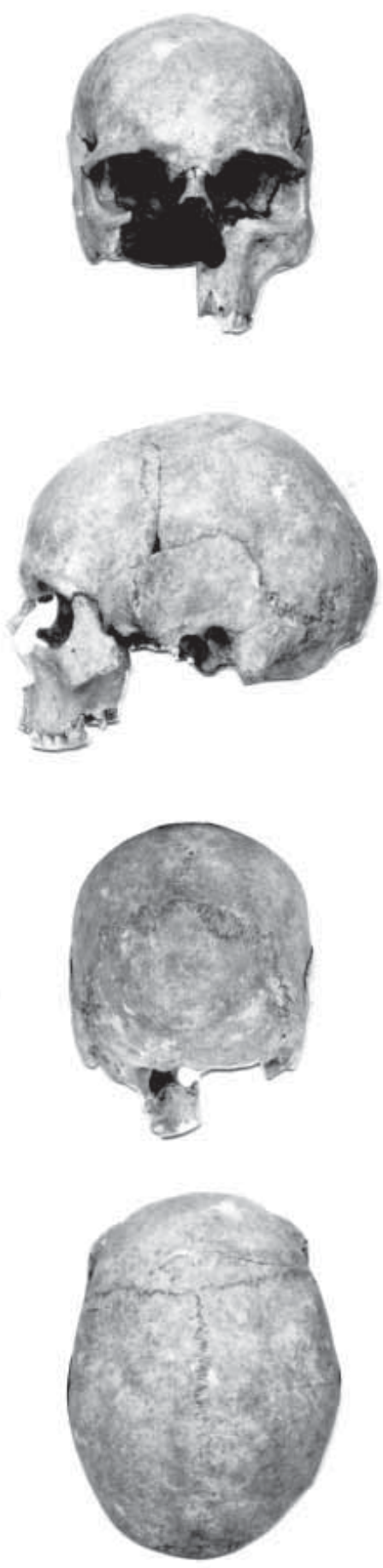

E
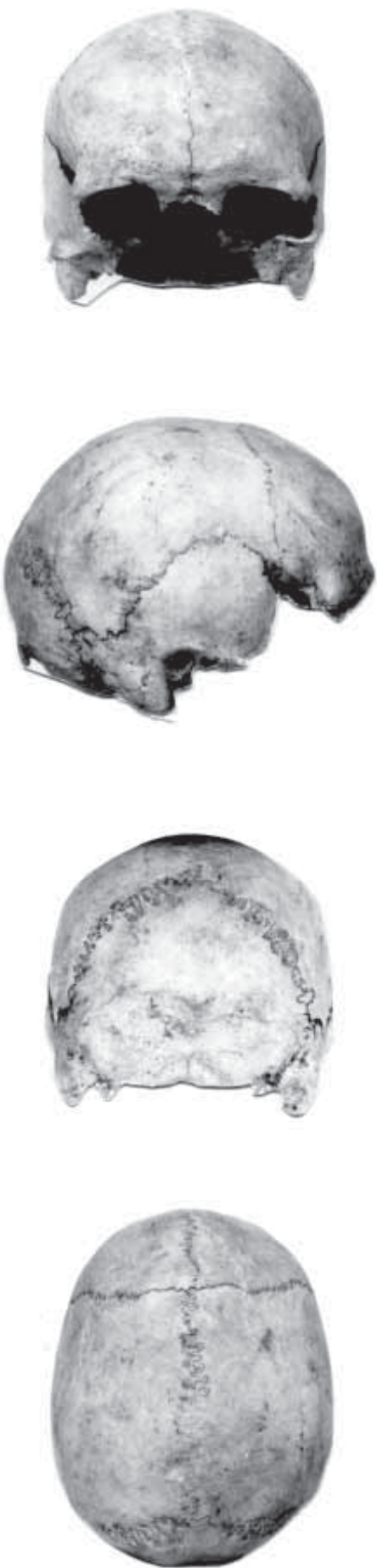

F
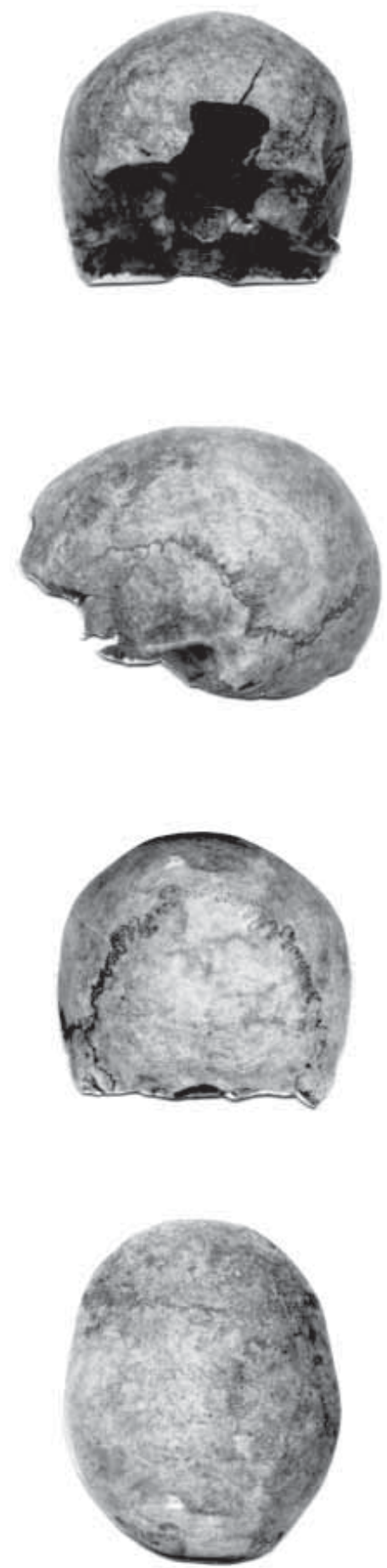

Fig. 3 Standardised anthropologic projection of skulls marked as D, E and F from grave G-769. 

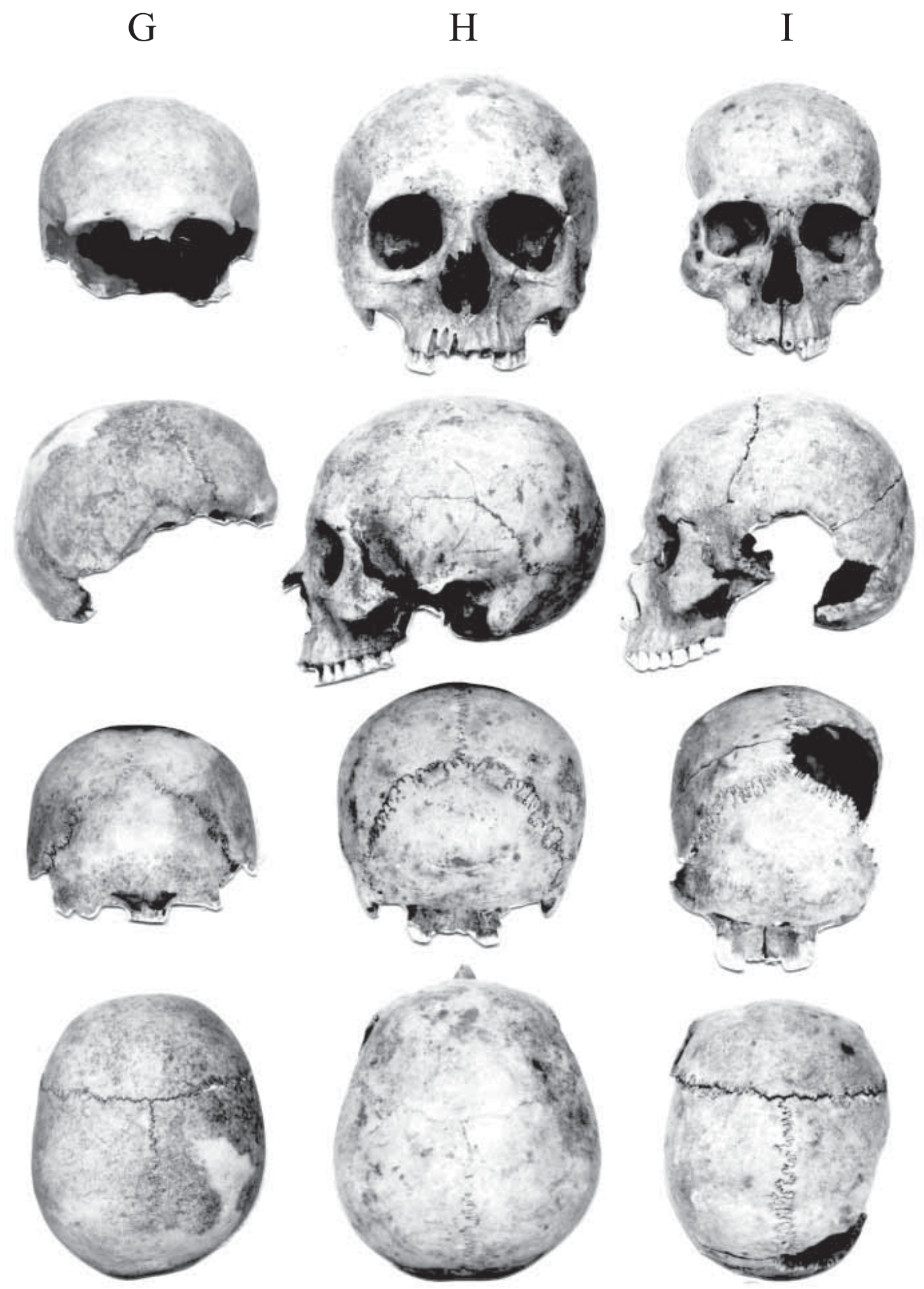

Fig. 4 Standardised anthropologic projection of skulls marked as G, H and I from grave G-769. 

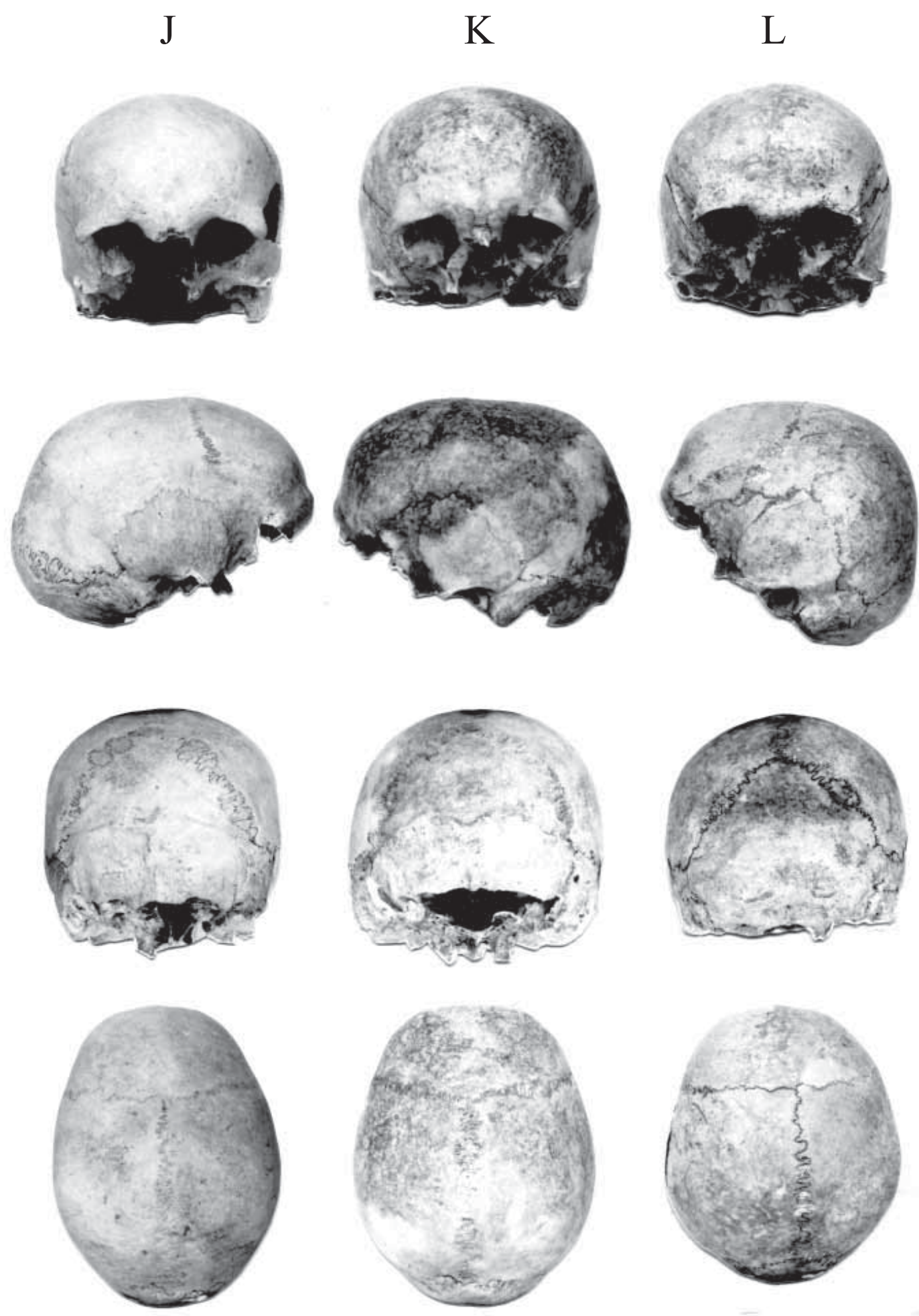

Fig. 5 Standardised anthropologic projection of skulls marked as J, K and L from grave G-769. 